\section{Case C-243/19 A v. Veselības ministrija}

Maastricht Journal of European and Comparative Law 202I, Vol. 28(6) 900-907 (C) The Author(s) 2021 Article reuse guidelines: sagepub.com/journals-permissions DOI: $10.1177 / 1023263 \times 211042465$ maastrichtjournal.sagepub.com

(SAGE

\begin{abstract}
The issue at stake in Case C-243/I 9 A v. Veselibas ministrija is whether a personal choice on the part of a patient, based on religious beliefs, must be considered when assessing the need for cross-border healthcare. The Court of Justice of the European Union holds that the Charter of Fundamental Rights of the European Union is applicable and the right to freedom of religion can be invoked, in addition to medical criteria. However, the sustainability of the healthcare system can be an objective justification for refusal to grant authorisation for cross-border healthcare. Furthermore, the case clarifies - to a certain extent - the parallel tracks for claiming cross-border healthcare.
\end{abstract}

\title{
Keywords
}

Cross-border healthcare, Regulation (EC) No 883/2004, Directive 201 I/24/EU, Charter of Fundamental Rights of the European Union, difference in treatment based on religion

\section{Introduction}

The case deals with the right to planned cross-border healthcare. Such healthcare can be granted under two instruments within EU law: Regulation 883/2004 ${ }^{1}$ and Directive 2011/24. ${ }^{2}$ The issue at stake in Case C-243/19 Av. Veselības ministrija ${ }^{3}$ is whether a person's religious beliefs entitles to healthcare in another Member State in a situation where the healthcare in the Member State of affiliation does not offer healthcare in accordance with the person's religious beliefs.

1. Regulation (EC) No 883/2004 of the European Parliament and of the Council of 29 April, 2004; on the coordination of social security systems, [2004] OJ L 166.

2. Directive 2011/24/EU of the European Parliament and of the Council of 9 March 2011 on the application of patients' rights in cross-border healthcare, [2011] OJ L 88.

3. Case C-243/19 A v. Veselības ministrija, EU:C:2020:872.

Associate Professor in European Law, Lecturer in Constitutional Law, Faculty of Law, Stockholm University

\section{Corresponding author:}

Jaan Paju Associate Professor in European Law, Lecturer in Constitutional Law, Faculty of Law, Stockholm University. Email: jaan.paju@juridicum.su.se 
In order to set the scene, the legal landscape will be described broadly, before Case C-243/19 is presented and discussed.

The original Member States treated healthcare as an inseparable part of social security, closely tied to the worker. ${ }^{4}$ In the original Regulation $3 / 58,{ }^{5}$ the coordination of healthcare focused on situations where a migrant worker ended up with no healthcare or limited access to healthcare. Article 19 Regulation 3/58 dealt with situations equivalent to those covered by today's 'blue card' and Article 20 addressed situations when workers and their family members lived in a Member State other than their Member State of affiliation. With the introduction of, Regulation 1408/71 succeeding Regulation 3/58, ${ }^{6}$ further rules were enacted, where migrant workers and their families could obtain healthcare in either the state of residence or the state of work. In addition to this, a new possibility was introduced in Article 22.1.c, which made it possible for the Member States to offer planned healthcare in another Member State when unable to provide its own healthcare within a reasonable amount of time. The possibility for cross-border healthcare was made dependent upon prior authorisation. Article 20 in the current Regulation 883/2004 lays down two cumulative conditions which, if fulfilled, require a Member State to grant authorisation. However, assessment lies with the Member States. ${ }^{7}$

The requirement for prior authorisation, as regulated by Regulation 1408/71, was challenged in $\mathrm{Kohll},{ }^{8}$ where the social security agency in Luxembourg refused to reimburse costs for an orthodontal treatment in Germany as there had been no prior authorisation. In Kohll, the Court of Justice of the European Union (CJEU) held that cross-border healthcare is understood as a service, despite being regulated in Regulation 1408/71. A requirement of a prior authorisation therefore constitutes a hindrance to the freedom to provide services. However, according to the CJEU, such national measures can be justified if there is an overriding public interest such as the sustainability of national healthcare systems. ${ }^{9}$ Kohll was followed by multiple referrals to the CJEU where the court opened for more extensive cross-border healthcare. ${ }^{10}$ The Patient Mobility Directive, Directive 2011/24, enacted in 2011, and national law implementing said directive, consolidated the case law.

Since Kohll and the opening of parallel tracks, the legal relationship between the free movement of services and Regulation 883/2004 has been largely unresolved. ${ }^{11}$ This unresolved relationship is clearly present in Case C-243/19. However, the CJEU clarified at least two

4. P. Roberts, 'A Short History of Social Security Coordination', in Y. Jorens (ed.), 50 Years of Social Security Coordination; Past-Present - Future, Report of the conference celebrating the 50th Anniversary of the European Coordination of Social Security, Prague, 7-8 May 2009 (EU Commission, DG Employment, 2009), p. 19.

5. Regulation 3/58 of 25 September 1958, [1958] OJ No 30.

6. Regulation (EEC) No 1408/71 of the Council of 14 June 1971 on the application of social security schemes to employed persons and their families moving within the Community, [1971] OJ L 149.

7. In the light of the strong reactions of the Member States in the Pierik saga, there is reason to believe that the Member States did not intend to introduce a right for the citizens; rather a possibility for more flexibility on the part of the Member States. See J. Paju, The European Union and Social Security Law (Hart Publishing, 2017), p. 107.

8. Case C-158/96 Kohll, EU:C:1998:171.

9. Ibid., para. 45 and 50.

10. Case C-160/96 Molenaar, EU:C:1998:84; Case C-368/98 Vanbraekel, EU:C:2001:400; Case C-157/99 Geraets-Smits \& Peerbooms, EU:C:2001:404; Case C-385/99 Müller Fauré \& Van Riet, EU:C:2003:270; Case C-372/04 Watts, EU: C:2006:325; Case C-173/09 Elchinov, EU:C:2010:581; Case C-777/18 Vas Megyei Kormányhivatal, EU:C:2020:745.

11. J. Paju, The European Union and Social Security Law, p. 117; R. Cornelissen, '50 Years of European Social Security Coordination', 12 European Journal of Social Security (2009), p. 9; p. 36. 
remaining issues: the material scope of the cross-border healthcare and on what terms refusal can be granted. It is also of great interest whether the Charter of Fundamental Rights of the European Union (the Charter) can be applied to Regulation 883/2004, a union law instrument that merely coordinates the Member States' independent healthcare systems. Both issues will be analysed here.

\section{Facts and preliminary questions}

The applicant A, affiliated to the Latvian healthcare system, had a minor son who suffered from a heart defect from birth. Due to this defect, the son required open-heart surgery. The applicant refused to consent to the use of a blood transfusion during the operation, as he was a Jehovah's Witness.

Operations of this kind without blood transfusion were not available in Latvia. The applicant requested the Nacionālais veselības dienests (the National Health Service of Latvia) to grant a prior authorisation for his son to be operated in Poland, where operations without blood transfusion were carried out.

The National Health Service refused to issue a prior authorisation for an operation in Poland where the costs would be covered by Latvia. The Ministry of Health upheld the health service's decision, on the grounds that the operation could be carried out in Latvia and that a person's religious beliefs could not be taken into consideration when assessing cross-border healthcare. The applicant brought an action before the District Administrative Court, which dismissed it. On appeal, the Regional Administrative Court upheld that judgment.

Despite the dismissed application, the applicant's son had heart surgery in Poland in April 2017.

Due to the dismissal, A brought an appeal on a point of law before the Latvian Supreme Court, arguing that he was a victim of discrimination since the vast majority of those affiliated to the healthcare system were able to receive the healthcare at issue without having to give up their religious beliefs.

The Latvian Supreme Court was uncertain whether the Latvian health authorities were entitled to refuse prior authorisation for treatment in Poland solely on medical criteria or whether the National Health Service also had to take account of A's religious beliefs. The court turned to the CJEU with two questions on whether cross-border healthcare must be granted with respect to freedom of religion and non-discrimination as follows from the Charter in cases where refusal of authorisation on medical grounds would be possible under Regulation 883/2004 and Directive 2011/24, respectively.

\section{The ruling of the CJEU}

The CJEU found that both Regulation 883/2004 and Directive 2011/24 were of relevance to the case. $^{12}$ Whereas the Advocate General discussed both laws in parallel, the CJEU chose to answer the referring court's questions separately. ${ }^{13}$

12. Case C-243/19 A v. Veselības ministrija, para. 57-64.

13. The reasoning of the CJEU largely follows the opinion of the Advocate General, despite no mention thereof. Therefore, the case note focuses mainly on the preliminary ruling of the CJEU. 


\section{Regulation 883/2004}

With regard to the material scope of cross-border healthcare, the CJEU found that cross-border healthcare under Regulation 883/2004 would be more generous than cross-border healthcare under the Directive. ${ }^{14}$ This initial finding plays a decisive role when assessing the possibility to claim medical care based on religious beliefs.

The CJEU held that the issuing of a prior authorisation under Regulation 883/2004 was exclusively concerned with medical needs, as the two conditions for granting authorisation in Article 20(1) both focus solely on a patient's medical situation. ${ }^{15}$ Hence, it is not possible to take personal choices, such as religious beliefs, into account when assessing an application for prior authorisation.

Concerning the son's operation, the CJEU found from the documents before the Court that there was no medical justification for an operation in Poland as, aside from the fact that the treatment was provided for by Latvian law, an operation could be given in good time. ${ }^{16}$ Given this, the question was whether A's claim that he was a victim of discrimination on religious grounds was to be considered. In other words, was the Charter to be applied? The CJEU answered in affirmative: The Charter was applicable as Member States are applying EU law when refusing a granting of prior authorisation. Therefore, when doing so, Member States are required to respect the fundamental rights guaranteed by the Charter. ${ }^{17}$

Despite the Charter being applicable, the CJEU followed the general principle lane. It noted that the general principles of equal treatment and discrimination based on religion are both expressed in the Charter. ${ }^{18}$

Being general principles, a difference in treatment is possible only if objectively justified and proportionate. The CJEU found that a difference in treatment was possible in this case as there was a potential risk of seriously undermining the financial balance of the Latvian social security system. This was the case as cross-border healthcare under Regulation 883/2004 is more onerous than under the Directive, since the Member State of affiliation has to reimburse the healthcare given by the Member State of residence. This, in contrast to the situation under the Directive, which covers only healthcare given in the Member State of affiliation and up to the level of said state's own tariffs. ${ }^{19}$ In other words: the burden is greater, therefore the room for manoeuvring for the Member States must be larger.

Taking this into account and referring to the subjective nature of religious beliefs, ${ }^{20}$ the CJEU found that if a Member State would, in addition to medical conditions, have to take account of religious beliefs, the resulting and unforeseeable additional costs could pose a threat to the financial stability of the system. ${ }^{21}$

14. Case C-243/19 A v. Veselības ministrija, para. 24.

15. Ibid., para. 25, 29 and 30 .

16. Ibid., para. 31 and 32 .

17. Ibid., para. 34 .

18. Ibid., para. 35 and 36 .

19. Cf. ibid., para. 48 and 49.

20. Cf. Advocate General Hogan who found that a fundamental right to religious freedom under the Charter could not be understood as requiring a public financial system that caters for individuals to practise their religious beliefs, Opinion of Advocate General Hogan in Case C-243/19 A v. Veselības ministrija, EU:C:2020:325, para. 82; see also R. McCrea, 'Article 10', in S. Peers et al., The EU Charter of Fundamental Rights (Hart Publishing, 2014), p. 303.

21. Case C-243/19 A v. Veselības ministrija, para. 50. 
Given this, the CJEU ruled that Article 20(2) of Regulation No 883/2004, read in the light of Article 21(1) of the Charter, must be interpreted as not precluding the insured person's Member State from refusing to grant that person an authorisation for treatment in another Member State where hospital care is available in the Member State, although the method of treatment used is contrary to that person's religious beliefs.

\section{Directive 201 l/24}

As for cross-border healthcare under the Directive, the prerequisites were somewhat different, the CJEU stated, as no additional financial burden would arise. Therefore, there was a systemic difference between the two reimbursement systems. This fact guided the CJEU's findings with regard to the possibility to make objective justifications. ${ }^{22}$

Initially, the CJEU found that the Member State of affiliation must reimburse the costs if the cross-border healthcare is amongst the benefits the person is entitled to. There were no cumulative conditions to be met, as in the case of Regulation 883/2004. On the contrary, the free movement of services would take precedence.

However, a Member State can, according to the Directive's Article 8(2)(a), introduce a system of prior authorisation in order to secure a sustainable healthcare system. Such a system is, under Article 8(6), restricted to medical conditions, just as the possibility to refuse the granting of prior authorisation under Regulation 883/2004. Though, two different perspectives and legislative systems, the balancing is the same: the medical condition is decisive. In light of this, the CJEU found that there was nothing that 'seriously' justified different interpretations as to the understanding of the prior authorisation systems. ${ }^{23}$ Hence, the CJEU bridged the two legal systems: the assessment of the medical conditions is the same.

As regards the Charter, the Court found that Member States when applying national law implementing the Directive it is a question of implementing law according to the Charter. This is fully in line with the common understanding of the Charter's applicability. ${ }^{24}$

However, with regard to justifying differences in treatment based on religious beliefs, the proportionality test differs depending on if the prior authorisation is performed under the Regulation or under the Directive. In the former case, the Member State of affiliation has to bear the costs, whereas in the latter case, the costs will be the same irrespective of whether the treatment have been carried out in the Member State of affiliation or in another Member State. ${ }^{25}$ In other words, it is not possible to argue that financial stability is at stake when prior authorisation for cross-border healthcare is granted under the Directive. Still, it is possible for Member States to argue the objective justification of maintaining treatment capacity or medical competence. That is, the CJEU rules, for the referring court to determine. $^{26}$

22. Ibid., para. 68 and 72 .

23. Case C-243/19 A v. Veselības ministrija, para. 82 .

24. Ibid., para. 83. Cf. Case C-292/97 Karlsson et al., EU:C:2000:202.

25. Ibid., para. 77, cf. the reasoning in Opinion of Advocate General Hogan in Case C-243/19 A v. Veselības ministrija, para. 85.

26. Case C-243/19 A v. Veselības ministrija, para. 79. 


\section{Conclusions}

\section{The interrelationship}

The interrelationship between the two legislative frameworks is complex, as Regulation 883/2004, and its predecessors, adds a free-standing right to cross-border healthcare rather than promoting the free movement of persons, whereas the Directive 2011/24 consolidates case law where the free movement of services is in focus. There is no common legal basis, therefore the perspectives differ. Thus, Case C-243/19 is to be welcomed as it sheds some light on the interrelationship between the two instruments.

In the past, the possibility of cross-border healthcare provided under the Regulation was to a large extent understood as an option for the Member States to purchase healthcare in other Member States, rather than being a right for individuals. ${ }^{27}$ For its part, the free movement of services is based on individuals' and companies' rights to receive and provide cross-border services.

Given this, the CJEU emphasises in the ruling that Article 20 of the Regulation should not be understood as an option for cross-border healthcare for Member States, rather the opposite. If the two cumulative conditions are met - a treatment provided by the Member State healthcare system and a medical condition that called for treatment - the Member State must grant prior authorisation. However, as hospital care is a benefit in kind, the healthcare given in another Member State is given according to that Member State's healthcare system and legislation. The CJEU thus sheds light on the difference between the two parallel systems: prior authorisation under the regulation is seemingly more generous as it opens for another Member State's treatments, not restricting the treatments to those offered by the Member State of affiliation. This can be of relevance when a patient seeks treatment abroad as another Member State might treat the same medical condition with a different (and perhaps more effective) method. Such a method cannot be called into question, unlike as it can be under Article 8(6)(c) of the Directive. However, any cross-border healthcare under Regulation $883 / 2004$ is restricted to hospitals tied to the social security schemes. Private health providers fall outside the scope of the Regulation. ${ }^{28}$

In addition, under Regulation 883/2004, Member States have to reimburse the full costs of the treatment, in contrast to in the case of cross-border healthcare under the Directive, where payment depends on the tariffs of the Member State of affiliation.

In summary, once a person is eligible for cross-border healthcare under the Regulation, the Member State of affiliation faces a greater financial risk than in the case of care under the Directive.

However, the CJEU sweetens the bitter pill in Case C-243/19 and hints that there is more leeway for objective reasoning under the Regulation than under the Directive. Also, overall costs can be found objectively reasonable. This finding can potentially play into the hands of the Member States: as long as they can play the financial stability card, they are safe, even if the cumulative conditions are met. Nevertheless, there must be a potential risk, not merely an unwillingness to grant cross-border healthcare. Still, the overall feeling is that cross-border healthcare under the Regulation remains a Member State affair.

The Directive, on the other hand, seems to have developed into a fully-fledged internal market instrument, despite the widespread hesitancy among the Member States during negotiations. With

27. D. Sindbjerg Martinsen, 'EU for the Patients: Developments, Impacts, Challenges', SIEPS (2007), p. 6; p. 14.

28. Under the Directive cross-border healthcare includes private health providers. 
64 recitals and only 23 substantive articles, the Directive clearly reflects this hesitancy. ${ }^{29}$ Nevertheless, once enacted, it opened for cross-border healthcare for other than purely medical reasons. However, most Member States have made use of the Directive's possibility of introducing prior authorisation before granting cross-border healthcare. ${ }^{30}$

The CJEU bridged the two legal instruments in Case C-243/19 and found that the medical assessment must be the same, regardless of which instrument is applied.

In the light of this, if cross-border healthcare is considered on basis of the Directive, a Member State cannot argue that the cross-border healthcare burdens the financial stability of its social security system, as the CJEU argues that 'the costs are the same'. This is however not true. The CJEU argues in Kohll that additional costs do not occur where the benefit is in cash, however, in C-243/19 the benefit (the hospital care) is in kind. Hospital care differs significantly from open day-care, which is easier to adjust according to a decrease in demand. Hence, the infrastructure costs with regard to hospital care in the Member State of affiliation remain. However, the CJEU sweetens the bitter pill by accepting that maintaining treatment capacity and medical competence is an objective justification. This calls however for a more complex line of reasoning, where costs make up only a part of the overall picture.

\section{The Charter}

The Charter was not intended to expand the de jure powers of the Union. Still, there were concerns it might de facto extend the Union's fundamental rights at the expense of the rights catalogues of the Member States. ${ }^{31}$ Accordingly, Article 51(1) of the Charter expressly ratifies the constitutional status quo: the Charter only applies, it explains, when Union law is being implemented. ${ }^{32}$ Furthermore, the preamble emphasises that the Charter only confirms and makes more visible powers and associated rights that already exist. This is also made very clear in the explanations ${ }^{33}$ relating to the Charter (here regarding Article 51): 'The fundamental rights as guaranteed in the Union do not have any effect other than in the context of the powers determined by the Treaties.'

In Dano, ${ }^{34}$ the CJEU ruled that the Charter was not of relevance, as Regulation 883/2004 does not implement Union law. The CJEU held that the Regulation, and thus the competence of the Union, is limited to determining the social security system of the Member State to which a migrating Union citizen is subject. ${ }^{35}$

In Case C-243/19, however - and this is the crux of the matter - we are dealing with substantive Union law, despite the overall character of Regulation 883/2004 as a coordination instrument. The Court established that the purpose of Article 20(2) of Regulation 883/2004 is to "confer a right to benefits...' 36 Thus, when a national authority rejects an application for prior authorisation for

29. The large number of recitals was one of many tactics used for reaching an agreement in the negotiations, cf. P. de la Rosa, 'The Directive on Cross-Border Healthcare or the Art of Codifying Complex Case Law', 49 CMLR (2012), p. 15; p. 28.

30. Twentythree Member States had introduced a system of prior authorisation by 2018, Member State Data on Cross Border Healthcare following Directive 2011/24/EU, Year 2018, https://ec.europa.eu/health/sites/default/files/cross_border_ care/docs/2018_msdata_en.pdf (visited 21.09.23)

31. Cf. T. von Danwitz and K. Paraschas, 'A Fresh Start for the Charter: Fundamental Questions on the Application of the European Charter of Fundamental Rights', 35 Fordham International Law Journal, 2012, p. 1397.

32. Ibid., p. 1398.

33. Explanations relating to the Charter of Fundamental Rights, [2007] OJ C 303.

34. Case C-333/13 Dano, EU:C:2014:2358.

35. Ibid., para. 89 and 90 .

36. Case C-243/19 A v. Veselības ministrija, para. 24. 
medical treatment in another Member State, it is not national law but rather Union law that is being applied. $^{37}$

It may seem the CJEU opened Pandora's box here, inasmuch as it found that the Charter applies to national social security systems in connection with cross-border healthcare. As this is a preliminary ruling, the CJEU underlined that it was up to the referring court to ascertain whether the decision not to allow healthcare in another Member State constituted a difference in treatment on the grounds of religion - and, if so, whether such a difference was justified on objective and reasonable grounds. ${ }^{38}$ However, in its extensive obiter dictum in para. 38-56, the CJEU was eager to direct the national court in its assessments. It held that, should the competent institution take subjective religious beliefs into account when assessing under Regulation 883/2004, the financial stability of the social security system would be affected as it would face an additional financial burden that would be difficult to foresee.

There is thus a legitimate objective justifying a difference in treatment. ${ }^{39}$ Nevertheless, the CJEU left the lid of Pandora's box slightly open, and it remains to be seen whether the box will be opened further in the future. The foundation has now been laid for the Charter having an impact in areas where Regulation 883/2004 entails substantive regulation, and not just coordination.

\section{Concluding words}

Case C-243/19 is interesting from many perspectives. The CJEU held that the Charter was applicable and the right to freedom of religion could be invoked in addition to medical criteria. However, as that freedom is of a subjective nature, the sustainability of the healthcare system can be an objective reason for refusing authorisation for cross-border healthcare. Furthermore, the case clarified the parallel tracks for claiming cross-border healthcare where healthcare under Regulation 883/2004, once granted, has greater consequences for the Member States than cross-border healthcare under Directive 2011/24. Therefore, the leeway for objective reasoning is greater under Regulation 883/2004 than under Directive 2011/24.

\section{Declaration of Conflicting Interests}

The author(s) declared no potential conflicts of interest with respect to the research, authorship, and/or publication of this article.

\section{Funding}

The author(s) received no financial support for the research, authorship and/or publication of this article.

\section{ORCID iD}

Jaan Paju (D) https://orcid.org/0000-0003-3839-3746

\footnotetext{
37. Ibid., para. 34.

38. Ibid., para. 38

39. Ibid., para. 39-53.
} 